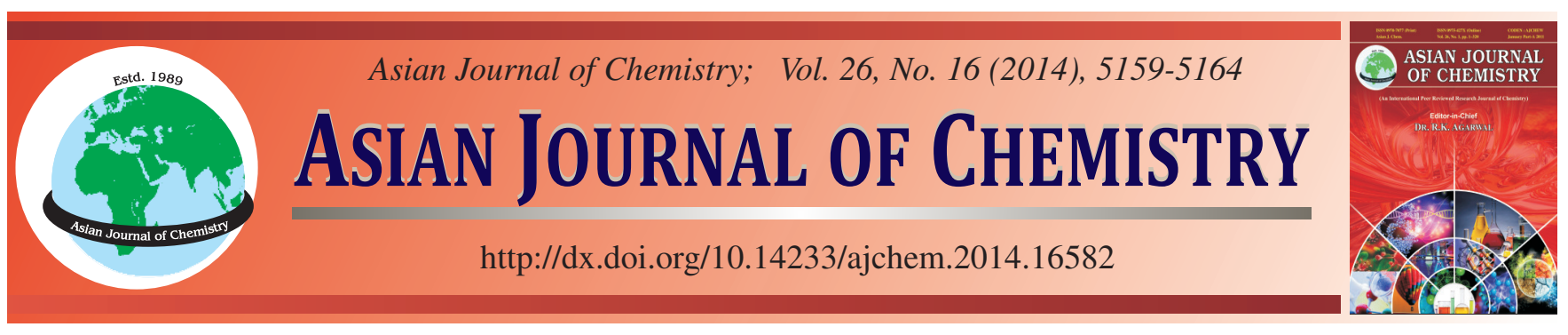

\title{
Antifungal and Bioherbicidal Properties of Essential Oils of Thymus fallax Fish \& Mey., Origanum vulgare L. and Mentha dumetorum Schult.
}

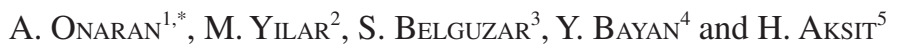

${ }^{1}$ Department of Plant Protection, Faculty of Agriculture, Ahi Evran University, 40200 Kirsehir, Turkey

${ }^{2}$ Organic Agriculture Department, Artova Vocational School of Higher Education, Gaziosmanpasa University, 60670 Artova, Tokat, Turkey

${ }^{3}$ Plant Protection Department, Faculty of Agriculture, Gaziosmanpasa University, 60240 Tokat, Turkey

${ }^{4}$ Plant Protection Department, Faculty of Agriculture, Sütçü Imam University, Kahramanmaras, Turkey

${ }^{5}$ Department of Chemistry, Faculty of Arts and Sciences, Gaziosmanpasa University, 60240 Tokat, Turkey

*Corresponding author: Fax: +90 386 2804832; Tel: +90 386 2804829; E-mail: abdonaran@ hotmail.com

The chemical composition of the essential oils obtained from the aerial parts of Thymus fallax, Origanum vulgare and Mentha dumetorum was analyzed by gas chromatography-mass spectrometry and the following were found to be the main constituents: T. fallax-thymol $(41.48 \%), o$-cymene $(26.75 \%), \zeta$-terpinen $(15.84 \%), 2$-isopropyl-1-methoxy-4-methylbenzene $(5.10 \%)$, terpineolene $(2.11 \%)$ and carvacrol (1.28 \%); O. vulgare-thymol (50.41\%), carvacrol (12.96\%), 2-bornene (11.28\%), $\zeta$-terpinen $(8.80 \%), o$-cymene $(6.68 \%)$, $\alpha$-bisabolane $(2.19 \%)$ and caryophyllene $(1.31 \%)$; and $M$. dumetorum-carvone (39.64\%), eucalyptol (14.34 \%), dihydrocarvone (12.78 $\%)$, limonene $(7.79 \%)$. The antifungal activities of the oils against Alternaria solani, Fusarium oxysporum and Rhizoctonia solani were also evaluated and were found to be toxic to the pathogens. The results revealed that essential oils, especially those of $T$. fallax and $O$. vulgare, had a strong antifungal activity with a significant inhibition on the growth of the 3 tested fungi. In contrast, the $M$. dumetorum oil did not inhibit the growth of Rhizoctonia solani and also exerted a limited inhibitory effect on the mycelial growth of the other two fungi tested. The results of herbicidal assays using these essential oils against four different plant species, Abutilon theophrasti Medik., Agrostemma githago L., Medicago sativa L. and Lepidium sativum L., showed that the oils had inhibitory effects on seed germination and seedling growth. The findings of the present study confirmed that plant essential oils can be used as natural herbicides and fungicides to control weeds and pathogenic fungi, thus, reducing the dependence on synthetic pesticides.

Keywords: Thymus fallax, Origanum vulgare, Mentha dumetorum, Essential oils, Biological activities.

\section{INTRODUCTION}

Recently, much research has been conducted on the increased food production that will be needed for the rapidly increasing world population and on synthetic pesticides, with the goal of reducing damage to the environment and human health.

Unfortunately, substantial yield losses occur due to insects and plant diseases caused by fungi, bacteria and viruses ${ }^{1,2}$. Synthetic chemicals (e.g., herbicides, fungicides and insecticides) are widely used in the control of plant diseases, pests and weeds. However, these chemicals may cause toxic residues in treated products ${ }^{3}$. As mentioned above, synthetic pesticides can also cause environmental pollution owing to their slow biological disruption ${ }^{4,5}$. In addition, other disadvantages of synthetic pesticide usage are the risk of resistance development by microorganisms, weeds and insects and the high cost of the products ${ }^{6-8}$.
Another major problem in world agriculture is the losses in crop yield caused by weeds; as a control measure, farmers have commonly applied herbicides to their crops. However, the wide use of synthetic herbicides has been demonstrated to cause pollution in soil and groundwater and lead to the development of weed resistance ${ }^{8,9}$. Furthermore, herbicides at high concentrations can also increase the risk of toxic residues in agricultural products. Therefore, scientists have searched for natural substances that have different and selective herbicidal mechanisms in comparison to their synthetic counterparts ${ }^{9-12}$.

In Turkey, aromatic plants are widely distributed and there are very rich and diversified florae and many of these plants have been recognized for their nutritional and medicinal characteristics. In Turkey, approximately 140 medical plants have been reported on to date. These plants are used in various industries, such as cosmetics, perfumes, detergents, pharmacology and food flavoring. However, a newly developing industry 
may be added to these traditional sectors i.e., the plant protection industry ${ }^{13,14}$.

The family Lamiaceae (Labiatae) is represented in Turkey by 46 genera and 571 species, of which $44.2 \%$ are endemic; including subspecies, varieties and hybrids, a total of 763 taxa exist. Thymus, Origanum and Mentha are well known genera in the Lamiaceae family ${ }^{15}$ and these genera have generally been used as traditional remedies to treat various ailments. For example, they are used as expectorant carminatives and aromatics to relieve whooping and convulsive coughs, digestive disorders and menstrual problems and as anesthetics, antiseptics, abortifacients and antirheumatics. Additionally, they can be used as antimicrobials, insecticides, antifungals and herbicides repellents ${ }^{11,16-21}$.

The objective of this study was to assess, the antifungal and bioherbicidal effects of essential oils on some pathogenic fungi and plant species. The toxicities of the volatile essential oils obtained from three plant species i.e., Thymus fallax, Origanum vulgare and Mentha dumetorum, were used in tests on plants (Abutilon theophrasti, Agrostemma githago, Medicago sativa and Lepidium sativum) and three plant pathogenic fungi (Alternaria solani, Fusarium oxysporum, Rhizoctonia solani).

\section{EXPERIMENTAL}

Plant material and the isolation of essential oils Thymus fallax and Origanum vulgare: The experimental plants were collected from Ordu/Turkey in July 2009 and were confirmed by Prof. Dr. Hamdi G. Kutbay, Department of Biology, Faculty of Science and Art, Ondokuz Mayis University. Mentha dumetorum was harvested from the Gaziosmanpasa University Agricultural Faculty test area in May of 2010. The essential oils were isolated from the plant materials using a water distillation technique via a Neo-Clevenger type apparatus. For the extraction of the volatile compounds, the plant materials were weighed $(100 \mathrm{~g}), 400 \mathrm{~mL}$ deionizer water was added and the distillation process was continued for approximately $2 \mathrm{~h}$. The essential oils were separated and dried with anhydrous $\mathrm{Na}_{2} \mathrm{SO}_{4}$ and stored in dark bottles at $4{ }^{\circ} \mathrm{C}$ until use and analysis.

Gas chromatography-mass spectrometry analysis: Gas chromatographic (GC) analyses were performed using a Perkin Elmer Clarus 500 Series GC system, in split mode, 50:1, equipped with a flame ionization detector (FID) and a mass spectrometer (MS) equipped BPX-5 apolar capillary column ( $30 \mathrm{~m} \times 0.25 \mathrm{~mm}$ and $0.25 \mathrm{~m}$ ID). Helium $(1 \mathrm{~mL} / \mathrm{min})$ was used as the carrier gas. The injector temperature was set at $250{ }^{\circ} \mathrm{C}$ and the FID was operated at $250{ }^{\circ} \mathrm{C}$. An initial column oven temperature of $50{ }^{\circ} \mathrm{C}$ was elevated to $220^{\circ} \mathrm{C}$ at a rate of $8{ }^{\circ} \mathrm{C} / \mathrm{min}$ and then held for $5 \mathrm{~min}$. The mass spectrometer conditions were as follows: Transfer line temperature at $250{ }^{\circ} \mathrm{C}$, ion source at $250{ }^{\circ} \mathrm{C}$ and the ionization energy at $70 \mathrm{eV}$. The standard components were available for the majority of the essential oil constituents and Kovats retention indices were determined for all of the sample components using the Van den Dool and Kratz equation according to the homologous $n$-alkane series retention times. Two MS libraries were used to confirm the identities of the compounds: Wiley MS Library and National Institute of Standards and Technology (NIST). Identification of the oil components was accomplished based on a comparison of their retention times with those of authentic standards (co-injection) and by a comparison of their mass spectral fragmentation patterns. The relative peak-area percentages of the compounds were calculated based on the FID data.

Antifungal activity assays: These assays were carried out to determine the effects of $T$. fallax, $O$. vulgare and $M$. dumetorum against $A$. solani, F. oxysporum and $R$. solani. The fungi were obtained from the culture collection at the Faculty of Agriculture, Department of Plant Protection at Gaziosmanpasa University, Tokat. The antifungal activity was studied using a contact assay (in vitro) that produces hyphal growth inhibition ${ }^{8}$. Sterile potato dextrose agar (PDA) was cooled in a water bath at $40{ }^{\circ} \mathrm{C}$ and the essential oils were mixed with the sterile PDA to obtain final concentrations of 125, 250, 500 and 1000 ppm. The PDA was poured into $90-\mathrm{mm}$ Petri plates $(15 \mathrm{~mL}$ plate-1). Then a agar disc (5 $\mathrm{mm}$ in diameter) of $A$. solani, $F$. oxysporum and $R$. solani were inoculated on the medium and the plates were incubated for 7 days at $25^{\circ} \mathrm{C}$. PDA without essential oils was used as a negative control and synthetic Maneb fungicide $(0.4 \mathrm{~g} / 200 \mathrm{~mL}$ PDA) was used as a positive control. The experimental design was a randomized block design with four replications per treatment. The radial growth of the fungi was recorded after 7 days.

The growth inhibition was calculated as the percentage of inhibition of radial growth relative to the control using the following equation ${ }^{8}$ :

$$
\text { Inhibition }(\%)=100 \times(\mathrm{C}-\mathrm{T}) / \mathrm{C}
$$

where $\mathrm{C}$ represents the mean of three replicates of hyphal extension $(\mathrm{mm})$ of the controls and $\mathrm{T}$ is the mean of three replicates of hyphal extension $(\mathrm{mm})$ of the plates treated with the essential oil. The experiment was repeated twice.

Seed germination and seedling growth experiments: The experiments were conducted in Petri dishes (60-mm diameter) containing two layers of filter paper. Depending on the species (i.e., Abutilon theophrasti, Agrostemma githago, Medicago sativa and Lepidium sativum), 15-25 seeds were homogeneously placed in each Petri dish and the dishes were watered using distilled water. Since essential oils have a low solubility in water, they were used in the gas phase. A given volume of each oil was placed on a piece of filter paper that was glued to the inside cover of each Petri dish ${ }^{11}$. The cover was closed and immediately sealed with parafilm. By using a micropipette, doses of 0 (control), 2, 5, 10 or $15 \mu \mathrm{L} /$ petri dish were applied. The experiments were conducted in four replicates. Petri dishes were incubated at an average temperature of $24{ }^{\circ} \mathrm{C}$ for 1 to 2 weeks, depending on the weed species. After the end of incubation period, the number of germinated seeds and seedling lengths were measured. The experiments were repeated twice.

Statistical analyses: The data were analyzed using the Analysis of variance (ANOVA) test. The means of treatments were grouped on the basis of least significant difference (LSD) at the 0.05 probability level. The SAS software was used to conduct all statistical analyses.

\section{RESULTS AND DISCUSSION}

The compositions of the volatile oils extracted by hydrodistillation from the aerial part of the plants are reported in Table-1, together with the Kovats' Indices (KI) calculated for 
each compound, the per cent composition and the identification methods. Approximately 24 (94.86\% of the total oil), 19 (98.26\% of the total oil) and 17 (97.51\% of the total oil) constituents were identified from the Mentha dumetorum, Thymus fallax and Origanum vulgare essential oils, respectively. The volatile compounds of $M$. dumetorum were found to be rich in carvone (39.69\%), eucalyptol (14.34\%), dihydrocarvone $(12.78 \%)$ and limonene $(7.79 \%)$. The T. fallax essential oils were found to be rich in thymol (41.48\%), o-cymene ( $26.75 \%)$, $\zeta$-terpinen (15.84\%) and 2-isopropyl-1-methoxy-4-methyl benzene (5.10\%), whereas the $O$. vulgare essential oil was rich in thymol (50.41 $\%)$, carvacrol (12.96\%), 2-bornene (11.28\%), $\zeta$-terpinen (8.80 $\%)$ and $o$-cymene $(6.68 \%)$. The GC-MS analysis of the oils showed an abundance of oxygenated monoterpenes in all of the plants $(76.35,48.44$ and $64.69 \%$, respectively, for M. dumetorum, T. fallax and $O$. vulgare). The monoterpene contents were 10.2, 48.57 and $29.32 \%$ for M. dumetorum, T. fallax and $O$. vulgare, respectively.

\begin{tabular}{|c|c|c|c|c|c|}
\hline \multicolumn{6}{|c|}{$\begin{array}{l}\text { TABLE-1 } \\
\text { ESSENTIAL OIL CONTENTS OF } M \text {. dumetorum } \\
\text { (MD), } T \text {. fallax (TF) AND } O \text {. vulgare (OV) PLANTS }\end{array}$} \\
\hline RI* & Compounds & $\mathrm{MD}$ & $\mathrm{TF}$ & OV & $\begin{array}{c}\begin{array}{c}\text { Identification } \\
\text { technique }\end{array} \\
\end{array}$ \\
\hline 953 & $\alpha$-Thujene & $-* *$ & 0.95 & $\operatorname{tr} * * *$ & MS, RI \\
\hline 965 & Camphene & - & 0.11 & - & MS, RI \\
\hline 988 & $\alpha$-Pinene & 0.41 & 0.45 & 0.73 & MS, RI \\
\hline 990 & $\beta$-Thujene & 0,23 & - & - & MS, RI \\
\hline 999 & $\beta$-Pinene & 1.05 & 0.95 & 0.54 & MS, RI \\
\hline 1013 & 3-carene & 0.20 & 0.68 & - & MS, RI \\
\hline 1022 & $\alpha$-phellandrane & 0.52 & 0.22 & $\operatorname{tr}$ & MS, RI \\
\hline 1033 & Terpineolene & - & 2.11 & 0.87 & MS, RI \\
\hline 1043 & $o$-cymene & - & 26.75 & 6.68 & \\
\hline 1048 & Linalaol formate & 1.46 & - & - & MS, RI \\
\hline 1067 & 3-octanol & 0.21 & - & - & MS, RI \\
\hline 1074 & $\zeta$-Terpinen & - & 15.84 & 8.80 & MS, RI \\
\hline 1102 & Limonene & 7.79 & 0.36 & 0.42 & Co-injection \\
\hline 1110 & Eucalyptol & 14.34 & 0.14 & $\operatorname{tr}$ & Co-injection \\
\hline 1247 & Thymolmethyleter & - & - & 0.94 & MS, RI \\
\hline 1257 & $\begin{array}{l}\text { 2-Isopropyl-1-methoxy-4- } \\
\text { methyl benzene }\end{array}$ & - & 5.10 & 0.38 & MS \\
\hline 1271 & Borneol & 1.31 & 0.11 & $\operatorname{tr}$ & Co-injection \\
\hline 1275 & 4-Terpineol & 0.47 & - & - & Co-injection \\
\hline 1294 & Dihydrocarvone & 12.78 & - & - & MS \\
\hline 1316 & Thymol & - & 41.48 & 50.41 & $\begin{array}{l}\text { Co-injection, } \\
\text { NMR }\end{array}$ \\
\hline 1322 & Carvacrol & - & 1.28 & 12.96 & $\begin{array}{l}\text { Co-injection, } \\
\text { NMR }\end{array}$ \\
\hline 1339 & Isopulegone & 0.53 & - & - & MS, RI \\
\hline 1348 & Carvone & 39.64 & 0.33 & - & Co-injection \\
\hline 1365 & 2-Bornene & - & 0.15 & 11.28 & MS, RI \\
\hline 1379 & Isobornylacetate & 0.32 & - & - & MS, RI \\
\hline 1418 & Dihydrocarveol & 5.32 & - & - & MS, RI \\
\hline 1481 & $\alpha$-Bourbonene & 3.57 & - & - & MS, RI \\
\hline 1501 & Methyl-eugenol & 0.21 & - & - & Co-injection \\
\hline 1521 & Caryophyllene & 1.73 & 1.06 & 1.31 & Co-injection \\
\hline 1525 & $\alpha$-bisabolane & $\operatorname{tr}$ & 0.20 & 2.19 & MS, RI \\
\hline 1532 & $\alpha$-cubebene & 0.27 & - & - & MS, RI \\
\hline 1548 & Germacrene & 0.50 & $\operatorname{tr}$ & & MS, RI \\
\hline 1572 & Isoledene & 0.55 & - & - & MS \\
\hline \multirow[t]{5}{*}{1596} & Copaene & 1.67 & - & - & MS \\
\hline & Monoterpens & 10.2 & 48.57 & 29.32 & \\
\hline & Oxygenated monoterpens & 76.35 & 48.44 & 64.69 & \\
\hline & Sesquiterpenes & 8.29 & 1.26 & 3.5 & \\
\hline & Total & 94.86 & 98.27 & 97.51 & \\
\hline
\end{tabular}

RI: Retention index, tr: $<0,05 \%$, nd: not detected; MS: Mass spectrophotometer
Antifungal activity of essential oils: The results obtained in the antifungal activity assays of the essential oils of $T$. fallax, $O$. vulgare and $M$. dumetorum against 3 agriculturally important fungal species are shown in Tables 2-4 and Figs. 1-3.

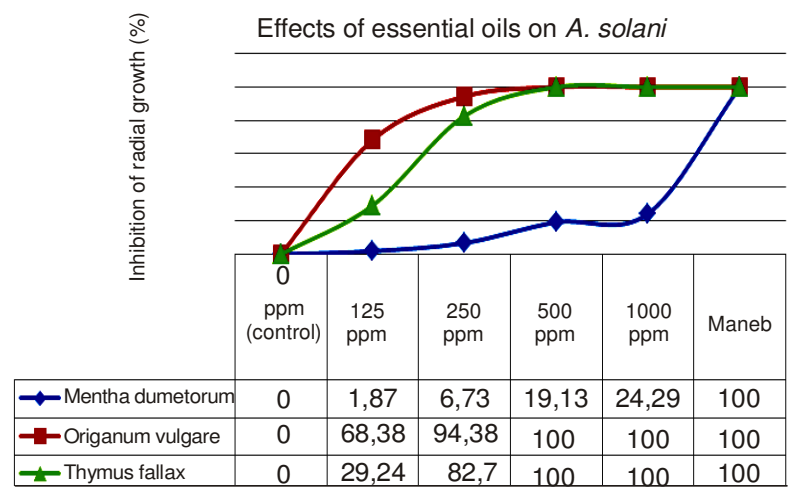

Fig. 1. Inhibitory effects on radial growth rates of essential oils on $A$. solani

TABLE-2

INHIBITORY EFFECTS OF ESSENTIAL OILS ON $A$. solani

\begin{tabular}{|c|c|c|c|}
\hline \multirow{2}{*}{$\begin{array}{l}\text { Treatments } \\
\text { (ppm) }\end{array}$} & \multicolumn{3}{|c|}{ Essential oils } \\
\hline & $\begin{array}{c}\text { Mentha } \\
\text { dumetorum }\end{array}$ & $\begin{array}{c}\text { Origanum } \\
\text { vulgare }\end{array}$ & Thymus fallax \\
\hline Control & $0.00 \mathrm{a}^{\mathrm{a}}(42.50)^{\mathrm{b}}$ & $0.00 \mathrm{a}(42.50)$ & $0.00 \mathrm{a}(42.50)$ \\
\hline 125 & $1.87 \mathrm{~b}(41.70)$ & $68.38 \mathrm{~b}(13.43)$ & $29.24 \mathrm{~b}(30.06)$ \\
\hline 250 & 6.73 c (39.63) & 94.38 c (2.87) & 82.70 c (7.34) \\
\hline 500 & 19. $13 \mathrm{~d}(34.36)$ & $100.00 \mathrm{c}(0.00)$ & $100.00 \mathrm{c}(0.00)$ \\
\hline 1000 & 24.29 e (32.17) & $100.00 \mathrm{c}(0.00)$ & $100.00 \mathrm{c}(0.00)$ \\
\hline Maneb & $100.00 \mathrm{f}(0.00)$ & $100.00 \mathrm{c}(0.00)$ & $100.00 \mathrm{c}(0.00)$ \\
\hline LSD & 3.44 & 7.30 & 6.26 \\
\hline
\end{tabular}

${ }^{a}$ Means in the same column with the same letter were not significantly different by ANOVA $(\alpha=0.05)$; ${ }^{\text {R }}$ adial growth after 7 days $(\mathrm{mm})$

TABLE-3

INHIBITORY EFFECTS OF ESSENTIAL OILS ON $F$. oxysporum

\begin{tabular}{|c|c|c|c|}
\hline \multirow{2}{*}{$\begin{array}{l}\text { Treatments } \\
\quad(\mathrm{ppm})\end{array}$} & \multicolumn{3}{|c|}{ Essential oils } \\
\hline & $\begin{array}{c}\text { Mentha } \\
\text { dumetorum }\end{array}$ & $\begin{array}{c}\text { Origanum } \\
\text { vulgare }\end{array}$ & fallax \\
\hline Control & $0.00 \mathrm{a}^{\mathrm{a}}(42.50)^{\mathrm{b}}$ & $0.00 \mathrm{a}(42.50)$ & $0.00 \mathrm{a}(42.50)$ \\
\hline 25 & 0. & 95) & 50) \\
\hline 50 & $12.24 \mathrm{c}$ & 63.71 & 60.6 \\
\hline 500 & $8.33 b c(38.95)$ & $95.96 \mathrm{~d}(1.71)$ & $98.03 \mathrm{c}(0.83)$ \\
\hline 1000 & $5.89 \mathrm{~b}(37.29)$ & $100.00 \mathrm{~d}(0.00)$ & $100.00 \mathrm{c}(0.00)$ \\
\hline Maneb & $54.63 \mathrm{~d}(19.27)$ & $54.63 \mathrm{c}(19.27)$ & $19.27 \mathrm{~b}(19.27)$ \\
\hline LSD & 4.36 & 9.24 & 3.72 \\
\hline
\end{tabular}

${ }^{2}$ Means in the same column with the same letter were not significantly different by ANOVA $(\alpha=0.05)$; ${ }^{b}$ Radial growth after 7 days $(\mathrm{mm})$

\begin{tabular}{|c|c|c|c|}
\hline \multicolumn{4}{|c|}{$\begin{array}{c}\text { TABLE-4 } \\
\text { INHIBITORY EFFECTS OF ESSENTIAL OILS ON } R \text {. solani }\end{array}$} \\
\hline \multirow{2}{*}{$\begin{array}{l}\text { Treatments } \\
\text { (ppm) }\end{array}$} & \multicolumn{3}{|c|}{ Essential oils } \\
\hline & $\begin{array}{c}\text { Mentha } \\
\text { dumetorum }\end{array}$ & $\begin{array}{l}\text { Origanum } \\
\text { vulgare }\end{array}$ & Thymus fallax \\
\hline Control & $0.00 \mathrm{a}^{\mathrm{a}}(42.50)^{\mathrm{b}}$ & 0.00 a (42.50) & $0.00 \mathrm{a}(42.50)$ \\
\hline 125 & $0.00 \mathrm{a}(42.50)$ & $0.00 \mathrm{a}(42.50)$ & $0.00 \mathrm{a}(42.50)$ \\
\hline 250 & 0.00 a $(42.50)$ & $82.90 \mathrm{~b}(7.26)$ & $0.00 \mathrm{a}(42.50)$ \\
\hline 500 & $0.00 \mathrm{a}(42.50)$ & $100.00 \mathrm{~b}(0.00)$ & $100.00 \mathrm{~b}(0.00)$ \\
\hline 1000 & $0.00 \mathrm{a}(42.50)$ & $100.00 \mathrm{~b}(0.00)$ & $100.00 \mathrm{~b}(0.00)$ \\
\hline Maneb & $100.00 \mathrm{~b}(0.00)$ & $100.00 \mathrm{~b}(0.00)$ & $100.00 \mathrm{~b}(0.00)$ \\
\hline LSD & 0.00 & 21.98 & 0.00 \\
\hline
\end{tabular}

${ }^{a}$ Means in the same column with the same letter were not significantly different by ANOVA $(\alpha=0.05)$; ${ }^{b}$ Radial growth after 7 days $(\mathrm{mm})$ 
TABLE-5

EFFECTS OF ESSENTIAL OILS ON THE GERMINATION AND ROOT AND SHOOT LENGTHS OF Abutilon theophrasti MEDIK. (MD, M. dumetorum; TF, T. fallax; OV, O. vulgare; GR, GERMINATION; RL, ROOT LENGTH; SL, SHOOT LENGTH)

\begin{tabular}{|c|c|c|c|c|c|c|c|c|c|c|c|c|}
\hline \multirow{2}{*}{$\begin{array}{l}\text { Treatments } \\
\text { (E. oils) }\end{array}$} & \multicolumn{3}{|c|}{$2 \mu \mathrm{L} /$ Petri dish E. oil } & \multicolumn{3}{|c|}{$5 \mu \mathrm{L} /$ Petri dish E. oil } & \multicolumn{3}{|c|}{$10 \mu \mathrm{L} /$ Petri dish E. oil } & \multicolumn{3}{|c|}{$15 \mu \mathrm{L} /$ Petri dish E. oil } \\
\hline & GR [\%] & $\mathrm{RL}[\mathrm{mm}]$ & $\mathrm{SL}[\mathrm{mm}]$ & GR [\%] & $\mathrm{RL}[\mathrm{mm}]$ & $\mathrm{SL}[\mathrm{mm}]$ & GR [\%] & $\mathrm{RL}[\mathrm{mm}]$ & SL $[\mathrm{m}]$ & GR [\%] & $\mathrm{RL}$ [mm] & $\mathrm{SL}[\mathrm{mm}]$ \\
\hline Control & $79.9 a^{a}$ & $18.5 \mathrm{a}$ & $16.1 \mathrm{a}$ & $79.9 a$ & $18.5 \mathrm{a}$ & $16.1 \mathrm{a}$ & $79.9 a$ & 18.5 & 16.1 & 79.9 & 18.5 & 16.1 \\
\hline $\mathrm{TF}$ & $35.5 b$ & $5.9 b$ & $4.6 \mathrm{~b}$ & $6.6 \mathrm{~b}$ & $1.9 \mathrm{~b}$ & $0.3 \mathrm{~b}$ & $2.2 \mathrm{~b}$ & 0.0 & 0.0 & 0.0 & 0.0 & 0.0 \\
\hline OV & $2.2 \mathrm{c}$ & $5.4 \mathrm{~b}$ & $0.0 \mathrm{c}$ & $0.0 \mathrm{~b}$ & $0.00 \mathrm{~b}$ & $0.0 \mathrm{~b}$ & $0.0 \mathrm{~b}$ & 0.0 & 0.0 & 0.0 & 0.0 & 0.0 \\
\hline MD & $0.0 \mathrm{c}$ & $0.0 \mathrm{~b}$ & $0.0 \mathrm{c}$ & $0.0 \mathrm{~b}$ & $0.00 \mathrm{~b}$ & $0.0 \mathrm{~b}$ & $0.0 \mathrm{~b}$ & 0.0 & 0.0 & 0.0 & 0.0 & 0.0 \\
\hline LSD & 17.33 & 6.049 & 4.486 & 10.16 & 3.198 & 1.640 & 7.661 & - & - & - & - & - \\
\hline
\end{tabular}

${ }^{\mathrm{a}}$ Means in the same column with the same letter were not significantly different by ANOVA $(\alpha=0.05)$

As shown in Table-2 and Fig. 1, the essential oil of $M$. dumetorum exhibited an inhibitory effect on the radial growth of $A$. solani. The observed inhibitory effects of $M$. dumetorum at $125-1000 \mathrm{ppm}$ varied between 1.87 and $24.29 \%$. In addition, the inhibition of the $M$. dumetorum oil on the growth of the tested fungi was significantly lower than Maneb and the oil was not active against $A$. solani. In contrast, T. fallax and $O$. vulgare oils at 250,500 and $1000 \mathrm{ppm}$ inhibited the radial growth of $A$. solani ( $100 \%$ inhibition) significantly compared with the control and showed a similar effect as Maneb (100\%).

It is speculated that the major components in the essential oils were probably responsible for the antimicrobial activity. As indicated in Table-1, the essential oil of $O$. vulgare contained mainly thymol, carvacrol, 2 -bornene, $\zeta$-terpinen and $o$-cymene. Lee et $_{\text {al }}{ }^{2}$ have reported that, the oil from $O$. vulgare inhibited the radial growth of Botrytis cinerea, Colletotrichum gloeosporioides, Fusarium oxysporum, Pythium ultimum and Rhizoctonia solani by 55, 78, 70, 93 and $68 \%$, respectively. The volatile terpenes, such as thymol, carvacrol and $o$-cymene, were thought to be responsible for the antifungal activity of O. vulgare oil ${ }^{2}$.

According to the Table-3 and Fig. 2, the inhibitory effect of $M$. dumetorum on the radial growth of $F$. oxysporum ranged from 0.00 to $12.24 \%$ at $125-1000 \mathrm{ppm}$ and showed lower antifungal effects than the other essential oils. Conversely, T. fallax and $O$. vulgare at 500 and $1000 \mathrm{ppm}$ showed complete inhibitory effects on the radial growth of $F$. oxysporum, which ranged from 95.96 to 100 and 98.03 to $100 \%$, respectively. Furthermore, the T. fallax and $O$. vulgare essential oils exhibited significantly higher inhibitory effects than Maneb at 250, 500 and $1000 \mathrm{ppm}$.

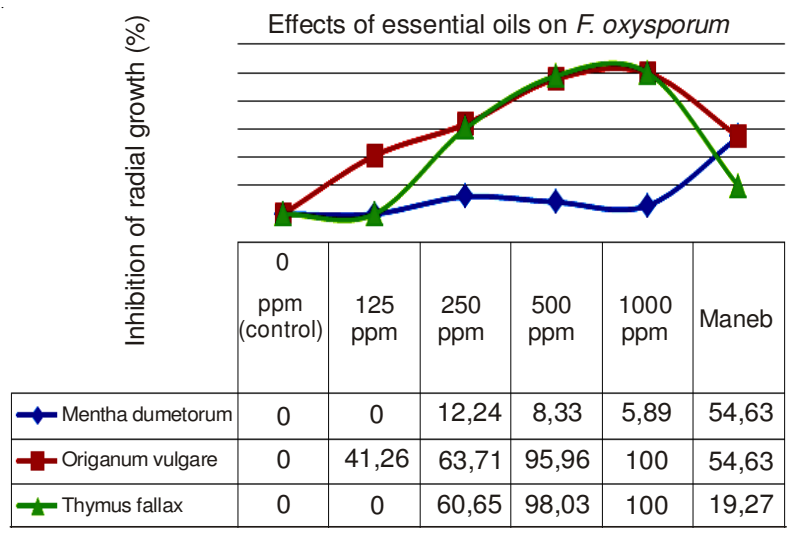

Fig. 2. Inhibitory effects on radial growth rates of essential oils on $F$. oxysporum
According to Table-4 and Fig. 3, the inhibitory effect of $M$. dumetorum on $R$. solani was not statistically significant compared with the control. Conversely, $T$. fallax and $O$. vulgare at 500 and 1000 ppm completely inhibited the radial growth of $R$. solani and the oils of $O$. vulgare and T. fallax caused $100 \%$ mycelial growth inhibition.

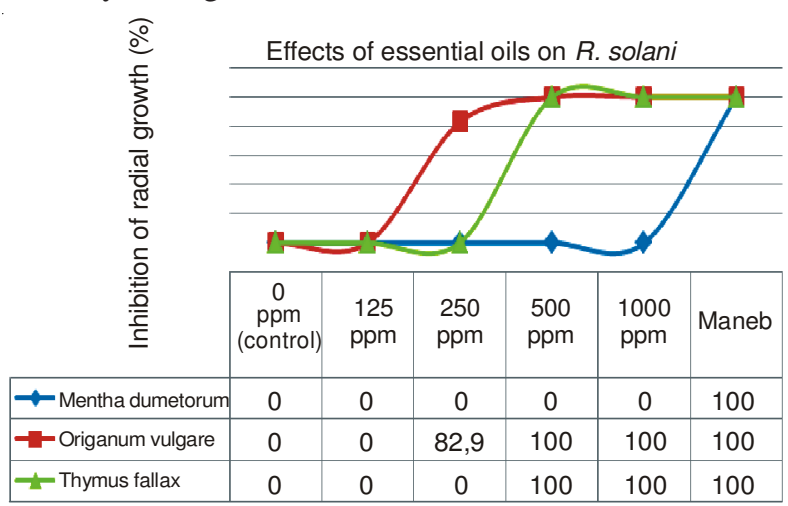

Fig. 3. Inhibitory effects on radial growth rates of essential oils on $R$. solani

In agreement with the results of the present study, Özcan and Boyraz ${ }^{22}$ have reported that the essential oil of Origanum vulgare completely inhibited the mycelial growth of $F$. oxysporum, $R$. solani and A. solani. The $10 \%$ level of the oregano decoctions were $100 \%$ inhibitive of mycelial growth in the culture medium at all of the incubation periods.

In previous studies, the methanol extract of $T$. fallax was reported to exert great antimicrobial activity, in particular against Arthrobacter atrocyaneus, Bacillus sphaericus, Enterobacter hormaechei, Staphylococcus cohnii, Pseudomonas syringae and Kocuria rosea. Inhibition of bacterial growth occurred at concentrations ranging from 31.25 to $500 \mu \mathrm{g} / \mathrm{mL}^{23}$.

Synthetic fungicides are widely used in the control of plant diseases. These chemicals may cause toxic residues in treated products, environmental pollution and resistance to fungicides among fungal pathogens. Therefore, alternative controls are needed. Because of the low toxicity in mammals, the reduced environmental effect and the wide public acceptance of plantderived products, researchers have looked to plants for new disease-control agents.

Lee et $a l^{2}$, have defined essential oils as concentrated, hydrophobic liquids containing volatile aromatic compounds extracted from plants, which are rich in bioactive chemicals and may provide potential alternatives to pesticides.

Bioherbicidal effects of the oils: In the present study, the essential oils of T. fallax, $O$. vulgare and $M$. dumetorum were tested on the seed germination and seedling growth of Abutilon theophrasti Medik., Agrostemma githago L., 
Lepidium sativum L. and Medicago sativa $\mathrm{L}$. and all were highly phytotoxic to seed germination and seedling growth of the tested plants.

Depending on the oil and dosage applied, a significant difference was observed on seed germination and the root and shoot length of $A$. theophrasti compared with the control. The results further revealed that, in general, the inhibitory effects of the essential oils on seed germination and seedling growth increased with increasing concentrations of the essential oils. The highest inhibitory effect on seed germination and seedling growth was obtained with the essential oil of M. dumetorum. The essential oils of T. fallax, O. vulgare and M. dumetorum completely inhibited the seed germination and seedling growth of $A$. theophrasti at a $15 \mu \mathrm{L}$ dosage (Table-5). In contrast, each of the concentrations of the essential oils of T. fallax, $O$. vulgare and $M$. dumetorum completely prevented the seed germination and seedling growth of A. githago L., L. sativum L. and M. sativa L. (Tables 6-8).

The differences in the efficacy of the essential oils were likely due to the variation in the components of the oils extracted from each test plant. The compositions of the essential oils used in the experiments were similar, but the proportional amounts of the basic components were found to differ. For example, the essential oil of $O$. vulgare contained approximately $50.41 \%$ thymol, whereas the essential oil of T. fallax contained approximately $41.48 \%$ thymol. The major component of the $M$. dumentorum essential oil was determined to be $39.64 \%$ carvone.

Recent studies have shown that both oxygenated monoterpenes and essential oils, which are relatively rich in oxygenated monoterpenes, possess strong inhibitory effects on seed germination and seedling growth ${ }^{8,11,20,24-27}$. In the present study, thymol, carvacrol, pinene, terpinene and borneol likely determined the herbicidal properties ${ }^{8,20,27-29}$ found in T. fallax, $O$. vulgare and $M$. dumetorum. However, we can not exclude that other major and/or minor component(s) in the essential oils (Table-1) may be responsible for the observed herbicidal effects; furthermore, synergistic and antagonistic interactions among the components are also possible.

The results presented in this study showed that the oils of T. fallax, $O$. vulgare and $M$. dumetorum have herbicidal effects against two important weeds that are commonly found in cultivated areas. A correlation has been established between phytotoxic essential oils and monoterpene components and observed anatomical and physiological changes to plant seedlings, leading to an accumulation of lipid globules in the cytoplasm, the reduction in some organelles, such as mitochondria and the inhibition of DNA synthesis as well as the disruption of membranes surrounding mitochondria and nuclei ${ }^{30-32}$. Under our experimental conditions, essential oils were found to exert highly phytotoxic effects on Lepidium sativum and Medicago sativa. Therefore, such herbicidal effects should be investigated further on other species.

\section{Conclusion}

Essential oils have strong inhibitory effects on the germination and seedling growth of weeds and the mycelium growth of plant pathogenic fungi. Therefore, essential oils are a potential source for the development of new bioherbicides and fungicides. These components should be tested for their bioherbicidal and antifungal activity on different weed species and plant pathogenic fungi.

TABLE-6

EFFECT OF ESSENTIAL OILS ON THE GERMINATION AND ROOT AND SHOOT LENGTHS OF Agrostemma githago

\begin{tabular}{|c|c|c|c|c|c|c|c|c|c|c|c|c|}
\hline \multirow{2}{*}{$\begin{array}{c}\text { Treatments } \\
\text { (essential oils) }\end{array}$} & \multicolumn{3}{|c|}{$2 \mu \mathrm{L} /$ Petri dish essential oil } & \multicolumn{3}{|c|}{$5 \mu \mathrm{L} /$ Petri dish essential oil } & \multicolumn{3}{|c|}{$10 \mu \mathrm{L} /$ Petri dish essential oil } & \multicolumn{3}{|c|}{$15 \mu \mathrm{L} /$ Petri dish essential oil } \\
\hline & GR [\%] & $\mathrm{RL}[\mathrm{mm}]$ & $\mathrm{SL}[\mathrm{mm}]$ & GR $[\%]$ & $\mathrm{RL}[\mathrm{mm}]$ & $\mathrm{SL}[\mathrm{mm}]$ & GR [\%] & $\mathrm{RL}[\mathrm{mm}]$ & $\mathrm{SL}[\mathrm{mm}]$ & GR [\%] & $\mathrm{RL}[\mathrm{mm}]$ & SL $[\mathrm{mm}]$ \\
\hline Control & 27.7 & 21.9 & 8.14 & 27.7 & 21.9 & 8.14 & 27.7 & 21.9 & 8.14 & 27.7 & 21.9 & 8.14 \\
\hline $\mathrm{TF}$ & 0.0 & 0.0 & 0.0 & 0.0 & 0.0 & 0.0 & 0.0 & 0.0 & 0.0 & 0.0 & 0.0 & 0.0 \\
\hline $\mathrm{OF}$ & 0.0 & 0.0 & 0.0 & 0.0 & 0.0 & 0.0 & 0.0 & 0.0 & 0.0 & 0.0 & 0.0 & 0.0 \\
\hline MD & 0.0 & 0.0 & 0.0 & 0.0 & 0.0 & 0.0 & 0.0 & 0.0 & 0.0 & 0.0 & 0.0 & 0.0 \\
\hline LSD & - & - & - & - & - & - & - & - & - & - & - & - \\
\hline
\end{tabular}

TABLE-7

EFFECT OF ESSENTIAL OILS ON THE GERMINATION AND ROOT AND SHOOT LENGTHS OF Lepidium sativum

\begin{tabular}{|c|c|c|c|c|c|c|c|c|c|c|c|c|}
\hline \multirow{2}{*}{$\begin{array}{c}\text { Treatments } \\
\text { (essential oils) }\end{array}$} & \multicolumn{3}{|c|}{$2 \mu \mathrm{L} /$ Petri dish essential oil } & \multicolumn{3}{|c|}{$5 \mu \mathrm{L} /$ Petri dish essential oil } & \multicolumn{3}{|c|}{$10 \mu \mathrm{L} /$ Petri dish essential oil } & \multicolumn{3}{|c|}{$15 \mu \mathrm{L} /$ Petri dish essential oil } \\
\hline & GR [\%] & $\mathrm{RL}$ [mm] & SL [mm] & GR [\%] & $\mathrm{RL}[\mathrm{mm}]$ & SL [mm] & GR [\%] & $\mathrm{RL}[\mathrm{mm}]$ & SL [mm] & GR [\%] & $\mathrm{RL}[\mathrm{mm}]$ & SL [mm] \\
\hline Control & 100 & 91 & 22.4 & 100 & 91 & 22.4 & 100 & 91 & 22.4 & 100 & 91 & 22.4 \\
\hline $\mathrm{TF}$ & 0.0 & 0.0 & 0.0 & 0.0 & 0.0 & 0.0 & 0.0 & 0.0 & 0.0 & 0.0 & 0.0 & 0.0 \\
\hline OV & 0.0 & 0.0 & 0.0 & 0.0 & 0.0 & 0.0 & 0.0 & 0.0 & 0.0 & 0.0 & 0.0 & 0.0 \\
\hline MD & 0.0 & 0.0 & 0.0 & 0.0 & 0.0 & 0.0 & 0.0 & 0.0 & 0.0 & 0.0 & 0.0 & 0.0 \\
\hline LSD & - & - & - & - & - & - & - & - & - & - & - & - \\
\hline
\end{tabular}

TABLE-8

EFFECT OF ESSENTIAL OILS ON THE GERMINATION AND ROOT AND SHOOT LENGTHS OF Medicago sativa

\begin{tabular}{|c|c|c|c|c|c|c|c|c|c|c|c|c|}
\hline \multirow{2}{*}{$\begin{array}{c}\text { Treatments } \\
\text { (essential oils) }\end{array}$} & \multicolumn{3}{|c|}{$2 \mu \mathrm{L} /$ Petri dish essential oil } & \multicolumn{3}{|c|}{$5 \mu \mathrm{L} /$ Petri dish essential oil } & \multicolumn{3}{|c|}{$10 \mu \mathrm{L} /$ Petri dish essential oil } & \multicolumn{3}{|c|}{$15 \mu \mathrm{L} /$ Petri dish essential oil } \\
\hline & GR [\%] & $\mathrm{RL}[\mathrm{mm}]$ & SL $[\mathrm{mm}]$ & GR [\%] & $\mathrm{RL}[\mathrm{mm}]$ & $\mathrm{SL}[\mathrm{mm}]$ & GR [\%] & $\mathrm{RL}[\mathrm{mm}]$ & SL $[\mathrm{mm}]$ & GR [\%] & $\mathrm{RL}[\mathrm{mm}]$ & SL [mm] \\
\hline Control & 86.6 & 30.3 & $\begin{array}{l}13.9 \\
\end{array}$ & 86.6 & 30.3 & \begin{tabular}{ll|}
13.9 \\
\end{tabular} & 86.6 & 30.3 & $\begin{array}{l}13.9 \\
\end{array}$ & 86.6 & 30.3 & 13.9 \\
\hline $\mathrm{TF}$ & 0.0 & 0.0 & 0.0 & 0.0 & 0.0 & 0.0 & 0.0 & 0.0 & 0.0 & 0.0 & 0.0 & 0.0 \\
\hline OV & 0.0 & 0.0 & 0.0 & 0.0 & 0.0 & 0.0 & 0.0 & 0.0 & 0.0 & 0.0 & 0.0 & 0.0 \\
\hline MD & 0.0 & 0.0 & 0.0 & 0.0 & 0.0 & 0.0 & 0.0 & 0.0 & 0.0 & 0.0 & 0.0 & 0.0 \\
\hline LSD & - & - & - & - & - & - & - & - & - & - & - & - \\
\hline
\end{tabular}




\section{ACKNOWLEDGEMENTS}

The authors are grateful to Prof. Yusuf Yanar, Department of Plant Protection, Faculty of Agriculture, Gaziosmanpasa University, for the help in checking the English.

\section{REFERENCES}

1. J. Fletcher, C. Bender, B. Budowle, W.T. Cobb, S.E. Gold, C.A. Ishimaru, D. Luster, U. Melcher, R. Murch, H. Scherm, R.C. Seem, J.L. Sherwood, B.W. Sobral and S.A. Tolin, Microbiol. Mol. Biol. Rev., 70, 450 (2006)

2. S.O. Lee, G.J. Choi, K.S. Jang, H.K. Lim, K.Y. Cho and J.C. Kim, Plant Pathol. J., 23, 97 (2007).

3. M.B. Isman, Crop Prot., 19, 603 (2000).

4. M. Barnard, M. Padgitt and N.D. Uri, Int. Pest Contr., 39, 161 (1997).

5. G. Misra and S.G. Pavlostathis, Appl. Microbiol. Biotechnol., 47, 572 (1997).

6. E. Roditakis, N.E. Roditakis and A. Tsagkarakou, Pest Manag. Sci., 61, 577 (2005)

7. H. Demirkan, Ege Üniv. Ziraat Fak. Derg, 46, 71 (2009).

8. S. Kordali, A. Çakir, T.A. Akçin, E. Mete, A. Akçin, T. Aydin and H. Kilic, Ind. Crops Prod., 29, 562 (2009).

9. S.O. Duke, F.E. Dayan, J.G. Romagni and A.M. Rimando, Weed Res., 40, 99 (2000).

10. N. Dudai, A. Poljakoff-Mayber, A.M. Mayer, E. Putievsky and H.R. Lerner, J. Chem. Ecol., 25, 1079 (1999).

11. H. Önen, Z. Özer and I. Telci, J. Plant Dis. Prot., 18, 597 (2002).

12. S. Kordali, A. Çakir and S. Sutay, Z. Naturforsch, 62, 207 (2007).

13. O. Çalmasur, I. Aslan and F. Sahin, Ind. Crops Prod., 23, 140 (2006).

14. 14. M.M. Bayramoglu, D. Toksoy and G. Sen, Türkiye'de Tibbi Bitki Ticareti. II. Ormancilikta Sosyo- Ekonomik Sorunlar Kongresi. 19-21 Subat, Isparta, Turkey (2009).
15. K.H.C. Baser and N. Kirimer, Acta Hortic., 723, 163 (2006).

16. B. Demirci, N. Tabanca and K.H.C. Baser, Flavour Fragrance J., 17, 54 (2002).

17. M.Z. Haznedaroglu, T. Oztürk and S. Konyalioglu, Salvia smyrnaea Boiss. uçucu yaginin antioksidan ve antimikrobiyal aktivitesi. 14. Bitkisel Ilaç Hammaddeleri Toplantisi, Bildiriler, 29-31 May 2002, Eskisehir, Turkey (2004).

18. A.P. Longaray Delamare, I.T. Moschen-Pistorello, L. Artico, L. AttiSerafini and S. Echeverrigaray, Food Chem., 100, 603 (2007).

19. B. Dulger and N. Hacioglu, Trop. J. Pharm. Res., 7, 1051 (2008).

20. S. Kordali, A. Çakir, H. Özer, H. Çakmakci, M. Kesdek and E. Mete, Bioresour. Technol., 99, 8788 (2008).

21. R. Kotan, S. Kordali, A. Cakir, M. Kesdek, Y. Kaya and H. Kilic, Biochem. Syst. Ecol., 36, 360 (2008).

22. M. Özcan and N. Boyraz, Eur. Food Res. Technol., 212, 86 (2000).

23. S. Öztürk and S. Ercisli, Pharm. Biol., 43, 609 (2005).

24. G.N. Dhanapal, P.C. Struik, P.C.J.M. Timmermans and S.J. Borg, J. Sustain. Agric., 11, 5 (1998).

25. H. Önen, J. Turk. Weed Sci, 6, 39 (2003).

26. H.P. Singh, D.R. Batish, N. Setia and R.K. Kohli, Ann. Appl. Biol., 146, 89 (2005)

27. L.F.R. de Almeida, F. Frei, E. Mancini, L. De Martino and V. De Feo, Molecules, 15, 4309 (2010)

28. L.G. Angelini, G. Carpanese, P.L. Cioni, I. Morelli, M. Macchia and G. Flamini, J. Agric. Food Chem., 51, 6158 (2003).

29. O. Messerschmidt, J. Jankauskas and F. Smith, US Patent, 2010/ 0216644,A1 (2010).

30. R. Koitabashi, T. Suzuki, T. Kawazu, A. Sakai, H. Kuroiwa and T. Kuroiwa, J. Plant Res., 110, 1 (1997)

31. J.A. Zygadlo and M.P. Zunino, Planta, 219, 303 (2004).

32. N. Nishida, S. Tamotsu, N. Nagata, C. Saito and A. Sakai, J. Chem. Ecol., 31, 1187 (2005). 